\title{
Climate Change and the Perspective of the Fish
}

Fundamentally the problem of climate change is a problem of arrogance and greed. If we want to seriously address the critical issues that face our world today we have to come up with something that is bold enough to allow us to say the unsayable. In other words, what is constructive in this search for answers is also what is most hard to say.

Arrogance and greed are human vices that speak to the weaker side of ourselves; to our vulnerabilities as humans. The arrogance that pervades the modern psyche is an arrogance that compromises the soul: that of a people, person, leader, parent or child. Arrogance and greed while seemingly easy to identify, are difficult to make transparent or even to avoid. Arrogance is the condition of presuming unfettered dominion over our environment and all living things. It is the ability to rationalise and believe that what is wrong is right.

Greed is the unhealthy preoccupation we have with profit, i.e. the accumulation of pecuniary or material gain for individual benefit at the unreasonable expense of others. Modern technology, industrialisation and mercantilism have allowed us to live a life of comfort literally at our fingertips. But this has come at a cost to our natural environment and spiritual health.

The dialogue on climate change is therefore not easy. Not just for the technicalities of understanding atmospheric changes and rising sea levels but equally, if not more so, for the soul-searching questions it forces us to confront about ourselves and our pursuits of wealth. The paradoxes of our modern economic philosophies come to light in this debate. The rationality of modern liberal economics finds as Raymond Aron points out, a "pessimism that sees, in politics, the art of creating the conditions in which the vices of men will contribute to the good of the state" (1957: 284). Recent comments on CNN about climate change and the world credit crisis puts it this way: "It is about having clean air and water" on one hand and "saving the United States not polar bears" on other. Climate change and the credit crunch graphically illustrate the crazy complexities of these paradoxes.

The nub question for me is how can I contribute to the conversation? In doing so let me own up that the biggest hurdle for me is to summon the courage to say something meaningful about climate change in the company of such eminent authorities. I come to these issues and questions with a heart full of anxieties, yet am buoyed by the belief that in the ultimate we have a common origin and destiny and are entrusted to search for insight and perspective, and hopefully for solutions, to the worst problems to have faced man.

His Highness Tui Atua Tupua Tamasese Ta'isi Efi, Head of Independent State of Samoa 


\section{A Different Paradigm}

In this common search, I offer the insights and perspectives of my Samoan indigenous reference or faasamoa. Within it is a worldview that privileges not just the perspective of other men, but of other living beings-of trees, animals, oceans and stars. It is a worldview or life principle that demands humility, sacrifice and respect of our sacred origins. This paradigm comes alive through the poetry, nuances and metaphors of our Samoan language, its legends, rituals and song chants. It tells of the importance of the principles of tapu, equivalence and affinity to overcoming arrogance and greed.

\section{Tapu and Sacrifice: The Story of Sina and Tuna}

The legend of Sina and Tuna is core to Samoan culture and is about the sacrifice of an unrequited love. An eel (Tuna) pines for Sina (a human girl) without avail. Unable to win her he eventually wills himself to death. His parting words to his beloved were: When I die cut my head off and bury it in the earth, it will grow into a tree whose leaves will weave mats and shutters; whose milk will sustain your thirst; and whose flesh will give you food. Every time you dehusk the nuts from this tree you and your descendants will see my face. And, every time you drink the milk from my mouth it will remind you of my undying love.

According to Samoan mythology this is the origin of the coconut tree, which is an essential feature of Samoan agriculture and spirituality. Today the leaves of the coconut tree are still used to weave mats and shutters for houses and to make food baskets. The coconut milk is still the principal beverage in Samoan society. And the flesh of the coconut is still staple food in our Samoan diet. The flesh is often grated and strained using sinnet to obtain cream and make oil. The cream provides flavour and taste to food; the oil can be used for massage and ritual blessings.

The metaphors of this story emphasise sacrifice. Arrogance is self-indulgence; greed is self-aggrandisement. Both are inimical to sacrifice. Tuna, despite being rejected, was able to rise above anger to leave a legacy of grace and humility. The coconut is tapu because it is reincarnation and when we eat the flesh of the coconut that is communion. Tuna as eel and as coconut tree demands a psychology whereby fish, plant and human are treated as co-inhabitors of the planet and actors in a common culture, where their desires and destinies are intertwined. When Tuna's head is buried in the earth there is connection with mother earth. Tuna's sacrifice brings blessings. The message is that what is good, decent and wholesome is spawned by sacrifice. 


\section{Affinity and Equivalence in Ritual Performance and Language}

In the village of Solosolo there is respect and public affinity between man and dog. The funeral ritual of Solosolo is honorifically named le maile i.e. dog. The people of Solosolo believe that the dog, when baying at the moon, is communicating with the cosmos and the gods. During the le maile funeral ritual performers transform themselves into dogs. They take on the persona of a dog through action, articulation and psyche. In behaving like a dog Solosolo connects "dogspeak" with "humanspeak" and celebrates affinity and equation between animal, cosmic and human life. Here man finds mystical connection between dog and moon reflective of a sacred relationship, a va tapuia.

In the village of Asau, the tautai or the head fisherman consults with his god about when to receive the tamasoaalii (honorific reference to the fish, i.e. mackerel). The relationship between the tautai and his god is tapu. On the designated day, early in the morning, the head fisherman, on his own, paddles his canoe to what is known as the ava o atule (literally, the entry of the mackerel).

Afio maia oe le manaia

Afio maia oe le tausala

O lea ua talisoa le aiga o

Tautaifau ma le au taliuta

O loo faatali Aiga ma Salafi ma

lo latou maopu

Afio mai oe le tamasoalii
Welcome to you the manaia-the honorific for the head of the untitled men's group

Welcome to you the tausala-honorific for the belle of the village ladies group

The fishing guild and the village await you

The village of Asau await you

I welcome you, the man who is the aide of the chief

The language used to address the mackerel is not common parlance or slang, it is chiefly language. In fact, here the head fisherman treats the mackerel as chiefs, evidenced by his specific use of chiefly honorifics. This is high praise. After the chant, the mackerel in reciprocal courtesy would follow the head fisherman into the net. This deference between man and fish underscores a mystical bonding that is celebrated by the Samoan saying: "le ia a le tautai e alu i le faalolo," meaning the fish defers to the will of the head fisherman. This mystical bonding speaks of a sacred affinity and equation between man and fish.

By today's reckoning the act of becoming a dog or addressing fish as chiefs can counteract man's arrogance as pre-eminent being. The sacred bonding between dog and moon or fish and tautai or head fisherman reflects a spiritual culture or a $v a$ tapuia (sacred relations) between humans, animals, cosmos and the gods. There is inherent respect for the sacred equivalence and affinity between them. 


\section{Respecting the Sacredness of Trees by Seeking Pardon}

In the debate on climate change the role of the trees and the forest as the "lungs of the earth" is critical to the production of clean air. In our Samoan reference trees have a life and soul and so are divine creations. Trees catch airborne pollutants by their leaves and bark, and through their root systems are able to cleanse ground water. They allow us to breathe clean air. In the Samoan indigenous context, if a tree was to be cut down, a prayer chant or faalanu is performed. The word used to describe the cutting of a tree is oia, which derives from the word oi, meaning to cry in pain. This presupposes that a tree suffers pain. The faalanu is performed to seek pardon for causing pain.

In the celebrated story of the canoe-builder Lata (or Rata in other parts of the Pacific), when failing to seek pardon from the spirit guardians of the forest for taking the life of a tree, he was denied use of the tree. In this story Lata was baffled to find that after felling during the day a tree from the forest in Savaii to build himself a canoe, that the next morning when he rose to start working on carving the canoe, the tree trunk was restored to life in its original place. On the third night of this happening Lata decided to hide during the night to see how the tree came back to life. After felling the tree he hid. Late into the night he saw female spirits encircling the tree, restoring it to life. He approached the spirit guardians and asked why they did this. They told him that he had disrespected them by failing to seek pardon before he fell the tree. Lata apologised and sought pardon. When he awoke the next morning the spirit guardians had carved him a beautiful canoe. The relationship between man and his environment, between man and his co-inhabitors is based on a spiritual culture that finds affinity and equivalence, balance and harmony, between them. In taking from the environment we are accountable to the environment.

\section{Conclusion}

The relationship between trees, animals, ocean and mother earth is one of balance, where boundaries are respected and protected. This is captured in the Samoan saying: e le la le uto i le maene pe sopo le tai i le eleele (lit. the floater cannot intrude on the function of the sinker, as the ocean cannot encroach on the boundaries of the land). In our arrogance and greed, we have encroached the boundaries of what is right and just. As we search for solutions we must be open to the wisdom of others. What has happened over the years as man has become more knowledgeable through science is that that very knowledge has given us a much greater capacity to abuse the elements and forget the need for harmony.

What we need in our search for balance and harmony is a culture of humility and sharing where arrogance and greed are openly admitted and addressed. This is the first step to healing. Man must have the courage to rise above himself and restore his 
fatumanava, i.e. the earth in his heart, and to find ways to connect (metaphorically) with the fish. I say the fish because I wish to end with a famous story from Robert Benchley, who while a student of International Law at Harvard University, made a joke about the perspective of the fish. The story goes that in a final examination Benchley was confronted with the question: Discuss the arbitration of the International Fisheries problem in respect to hatcheries protocol and dragnet and trawl procedure, as it affects (a) the point of view of the United States; and (b) the point of view of Great Britain. In addressing the question Benchley wrote desperately: "I know nothing about the fisheries problem; and nothing about the point of view of the United States; and nothing about the point of view of Great Britain. Therefore, I shall discuss the question from the point of view of the fish."

Humour aside, for the climate change debate there is poignancy here in searching for the perspective of the fish. For Samoans, there is a sacred essence, equivalence and affinity between man and fish. To find solutions to our current environmental problems we must ask ourselves what it is to be a fish. To do this you must be prepared to enter the mind of the fish, to become them, to live as them, and experience the sacrifice they might have to make in order to survive. To protect the environment, you need to be able to respect the environment. The relevance of the viewpoint of the fish is embedded in the wisdom of Robbie Burns:

Would some power the gift to give us

To see ourselves as others [the fish and trees] see us.

Soifua. ${ }^{1}$

1 Presented to the Stars of Oceania Summit, University of Hawai‘i, 9-12 April 2009. 
